\title{
Isotopo egonkorrak elikadura eta mugikortasun ikerketetan: Erdi Aroko zenbait aztarnategiren kasuak
}

(Diet and mobility studies based on stable isotopes:

Same Middle Age graveyard examples)

Iranzu Guede*, Ainhoa Alonso-Olazabal, Maria Cruz Zuluaga, Luis Angel Ortega

Mineralogia eta Petrologia Saila, Zientzia eta Teknologia Fakultatea, Euskal Herriko Unibertsitatea (UPV/EHU)

LABURPENA: Gizakien hezur eta hortzetan neurtutako isotopo-erlazioak $\left({ }^{87} \mathrm{Sr} /{ }^{86} \mathrm{Sr}\right.$, $\delta^{13} \mathrm{C}, \delta^{15} \mathrm{~N}$ eta $\delta^{18} \mathrm{O}$ ) antzinako gizakien elikadura eta mugikortasun-ereduak berreraikitzeko erabiltzen dira. Gizakien elikaduraren berri izateko, gizaki eta faunaren hezurretik lortutako kolagenoan karbono eta nitrogeno isotopoen analisiak egiten dira. Gainera, gizaki eta animalien mugikortasunari buruzko informazioa lortzeko, hezur eta hortzetan neurtutako estrontzio eta oxigenoen isotopo-erlazioak erabiltzen dira. Isotopo hauek duten aplikazioa ikusteko Erdi Aroko hiru aztarnategiren emaitzak deskribatuko dira, Momoitioko San Juan (Bizkaia), Tauste (Zaragoza) eta Las Gobasekoak (Trebiñuko Konderria), hain zuzen ere.

HITZ GAKOAK: isotopo-erlazioak, isotopo egonkorrak, elikadura, mugikortasuna, Erdi Aroa.

ABSTRACT: The isotope relations measured in human bone and teeth $\left({ }^{87} \mathrm{Sr} /{ }^{86} \mathrm{Sr}\right.$, $\delta^{13} C, \delta^{15} N$, and $\delta^{18} \mathrm{O}$ ) are used to rebuild diet and mobility patterns. Carbon and nitrogen isotopes applied on the collagen from human and fauna bones are used to study the diet. On the other hand, strontium and oxygen isotope relations measured in the teeth have been used in human mobility studies. This work also shows the results of three archaeological sites of Middle Age to see the application of these methods. The used archaeological sites have been San Juan de Momoitio (Biscay), Tauste (Zaragoza) and Las Gobas (Treviño).

KEYWORDS: isotope relation, stable isotopes, diet, mobility, Middle Age.

\footnotetext{
* Harremanetan jartzeko / Corresponding author: Iranzu Guede, Mineralogia eta Petrologia saila, Zientzia eta Teknologia Fakultatea, (UPV/EHU), Sarriena auzoa, zg (48940 Leioa-Bizkaia). - iranzulaura.guede@ehu.eus - https://orcid.org/00000002-3025-1711.

Nola aipatu / How to cite: Guede, Iranzu; Alonso-Olazabal, Ainhoa; Zuluaga Maria Cruz; Ortega, Luis Angel (2019). «Isotopo egonkorrak elikadura eta mugikortasun ikerketetan: Erdi Aroko zenbait aztarnategien kasuak»; Ekaia, 36, 2019, 255-274. (https://doi.org/10.1387/ekaia.20841).

Jasoa: 13 maiatza, 2019; Onartua: 10 uztaila, 2019

ISSN 0214-9001 - eISSN 2444-3255 / (c) 2019 UPV/EHU

(c) (i) (2) Obra hau Creative Commons Atribución 4.0 Internacional-en 
Iranzu Guede, Ainhoa Alonso-Olazabal, Maria Cruz Zuluaga, Luis Angel Ortega

\section{SARRERA}

Azken urteetan antzinako biztanleriaren bizimoduaren nondik norakoak interes handia piztu du eta haren inguruko ikerketak areagotu egin dira. Duela gutxi arte ikerketa hauek indusketetan aurkituriko material arkeologikoan (fauna, aztarna makro-botanikoak, polena, zeramikak, koprolitoak) oinarritzen ziren, bai eta zeharkako iturrietan ere (esate baterako, hezur-patologia edo hortzen higienearen ereduen azterketa). Azken hamarkadetan, ordea, teknologiaren aurrerapenei esker, antzinako bizimoduaren berri izateko, gizakien aztarnetan - hortz eta hezurretan - burutzen diren analisi isotopikoetan oinarritzen diren elikadura eta mugikortasun-ikerketak ere burutzen dira. Isotopoen erabilera hau indusketetan aurkitutako informazio arkeologikoari osagarria da. Gizakiek utziriko aztarnetan, hezur eta hortzetan alegia, neurturiko isotopo-erlazioen bidez elikadura eta mugikortasunari buruzko informazioa jasotzeaz gain, modu ez zuzen batean ikertutako biztanleriaren egitura sozial eta ekonomikoari buruzko informazioa ere lortzen da.

Lan honetan, metodologia honen oinarrizko azalpenak eta gizakien elikadura- eta mugikortasun-ikerketetan karbono-, nitrogeno-, oxigeno- eta estrontzio-isotopoek duten balioa deskribatuko dira. Aldi berean, isotopo egonkorren erabilgarritasuna ikusi ahal izateko, azken urteetan gure ikerketa taldeak Erdi Aroko Ipar Iberiar Penintsulan kokatzen diren hiru aztarnategiren dieta eta mugikortasunaren emaitza batzuk aurkeztuko dira. Aztarnategi horiek VI.-XIII. mendeetakoak diren Momoitioko San Juan (Bizkaia), Tauste (Zaragoza) eta Las Gobas (Trebiñuko Konderria) dira (1. irudia).

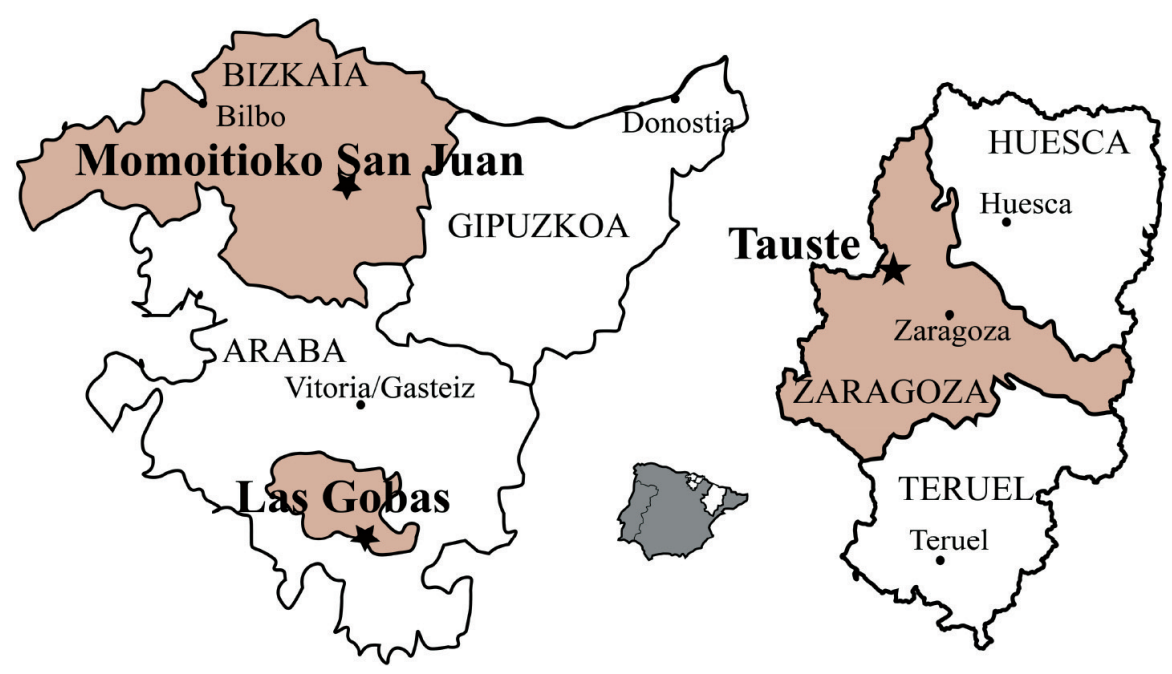

1. irudia. Lan honetan deskribatutako Momoitioko San Juan, Las Gobas eta Tauste aztarnategien kokapen geografikoa. 


\section{ISOTOPO EGONKORRAK ETA ADIBIDEAK}

Isotopoak protoi kopuru berbera eta neutroi kopuru desberdina duten elementu kimiko beraren atomoak dira. Isotopoek propietate kimiko berberak dituzte, eta erakusten duten desberdintasun bakarra masa-zenbakiari dagokio. Isotopoen artean bi talde bereizten dira: erradioaktiboak eta egonkorrak. Isotopo erradioaktiboak egoera ezegonkor batean aurkitzen dira eta denboran zehar konfigurazio egonkorragoak lortzeko berez desintegratzen direnak dira. Elementu kimiko baten isotopo-konposizio portzentajeetan edo, modu egokiagoan, isotopoen arrazoietan adierazten da. Isotopo egonkorrak, bestalde, desintegratzen ez diren isotopoak dira, eta haien ugaritasuna ez da aldatzen denborarekin, baina isotopo-frakzionazioa deritzon fenomenoa pairatzen dute. Prozesu kimiko, fisiko edo biologikoetan edozein elementuren isotopoek bata bestearengandik pixka bat desberdin jokatzen dute, prozesu batean isotopo batek bestearekiko lehentasuna izaten baitu isotopo-arrazoiak aldatuz. Horixe da isotopo-frakzionazioa. Isotopo-konposizio aldaketa horiek oso txikiak dira, eta $\delta$ unitatetan adieraz daitezke.

$\delta$ isotopo astuna $\% o=\frac{\text { laginaren isotopo arrazoia }- \text { estandarraren isotopo arrazoia }}{\text { estandarraren isotopo arrazoia }} \times 10^{3}$

Isotopo egonkorren balioak, $\delta$ ikurrak, laginaren isotopo astunaren eta arinaren arteko erlazioa estandarrenarekiko adierazten du milakoetan (\%o). Delta negatiboa bada, lagina isotopo astunean estandarra baino txiroagoa izango da. Isotopo egonkorrei loturiko «aberatsa» eta «txiroa» terminoak, formulan zenbakitzaileko isotopo-arrazoiari erlazionatua dago, isotopo astunarekin hitzarmenez. Estandarra, komeni denaren arabera aukeratzen da, eta itsasoko ura ${ }^{18} \mathrm{O} /{ }^{16} \mathrm{O}$, itsas kareharria ${ }^{13} \mathrm{C} /{ }^{12} \mathrm{C}$, belemnite lagina ${ }^{13} \mathrm{C} /{ }^{12} \mathrm{C}$, atmosferako nitrogenoa ${ }^{15} \mathrm{~N} /{ }^{14} \mathrm{~N}$ eta abar izan daiteke.

Elikadura- eta mugikortasun-ikerketetan karbono $\left(\delta^{13} \mathrm{C}\right)$, nitrogeno $\left(\delta^{15} \mathrm{~N}\right)$, oxigeno $\left(\delta^{18} \mathrm{O}\right)$ isotopo egonkorrak eta estrontzio-isotopo arrazoiak $\left({ }^{87} \mathrm{Sr} /{ }^{86} \mathrm{Sr}\right)$ erabiltzen dira.

Isotopoen analisiari dagokionez, masa-espektrometroak erabiltzen dira. Karbono eta nitrogeno isotopo-erlazioak fluxu jarraiko isotopo-erlazio masa-espektrometroaren (EA-IRMS) bidez neurtu dira Iso-Analytical laborategian (Cheshire, Erresuma Batua). Estrontzio isotopo-erlazioen analisiak, aldiz, Euskal Herriko Unibertsitateko UPV/EHU SGIker zerbitzuko induktiboki akoplatutako plasma-iturridun bereizmen handiko masa-espektrometroan (MC-ICP-MS, Neptune) burutu dira, eta, azkenik, oxigeno isotopoen analisiak, Parma Unibertsitateko (Parma, Italia) Thermo Finnigan Delta plus XP isotopo-erlazio masa-espektrometro (IRMS) bati loturik dagoen fluxu jarraiko tenperatura altuko konbertsio-analizatzaile elementala (TCEA) eta analizatzaile elementala (EA) duen batekin neurtu dira. 
Iranzu Guede, Ainhoa Alonso-Olazabal, Maria Cruz Zuluaga, Luis Angel Ortega

\subsection{Karbonoaren eta nitrogenoaren isotopo egonkorrak}

Karbono- eta nitrogeno-isotopo egonkorrak aspalditik erabili izan dira geologiaren esparruan, esate baterako, mineralen inklusioen edo diamanteen isotopo-konposizioa ezagutzeko [1-4], petrolioaren esplorazioan [5-8], besteak beste. Azken hamarkadetan metodologia honen aplikazioa beste arlo batzuetara zabaldu da, eta horien artean, arkeologian esate baterako, isotopo egonkorren analisia iraungita dauden espezieen elikadura eta maila trofikoa zehazteko erabiltzen dira, gizakia barne. Karbono eta nitrogeno isotopo-erlazioak hezurretatik lortutako kolagenoan neurtzen dira. Izan ere, jan eta edaten dugunaren isotopo-konposizioa gorputzeko ehun guztietara pasatzen da, eta, beraz, gizakien aztarnetan neurtzen den isotopo-konposizioa, jan eta edandakoaren konposizio isotopikoaren isla izango da. Hala eta guztiz ere, isotopo-konposizioak ez ditu elikagai edo dieta jakin batzuk identifikatzen [9], baizik eta proteina iturri nagusien ezagutza ahalbidetzen du. Horrela, Kretazeoko dinosauroen elikadura ezagutzeko [10] erabili izan dira, baita Pleistozenoko ugaztun ezberdinen elikadura ezagutzeko ere, esate baterako leize-hartzarena [11,12] eta mamutarena [13]; bestalde, Australopithecus [14] eta Neanderthalen dietak [15-16] ere ikertu dira.

\subsubsection{Karbono-isotopo egonkorrak}

Karbono-isotopoen konposizioa $\delta^{13} \mathrm{C}$ moduan adierazten da eta Pee Dee Belemnite (PDB) modura ezagutzen den belemnite estandarrarekiko kalkulatzen dira, honako formula honi jarraituz:

$$
\delta{ }^{13} \mathrm{C}(\%)=\left[\left({ }^{13} \mathrm{C} /{ }^{12} \mathrm{C}_{\text {lagina }} /{ }^{13} \mathrm{C} /{ }^{12} \mathrm{C}_{\mathrm{PDB}}\right)-1\right] \times 1.000
$$

Dietari buruzko ikerketetan, karbono-isotopoen analisiak zenbait landaretza mota desberdintzeko erabiltzen dira. Fotosintesia emateko moduaren arabera, landareek karbono isotopo-arrazoi desberdinak dituzte, landare batzuk nahiago dutelako karbono isotopo astuna $\left({ }^{13} \mathrm{C}\right)$ eta beste batzuek isotopo arina $\left({ }^{12} \mathrm{C}\right)$. Horrela, fotosintesi moduaren arabera, bi landare mota daude: C3 eta C4 landareak. Fotosintesi prozesuan C3 landareek nahiago dute ${ }^{13} \mathrm{C}$ isotopo astuna; aldiz, $\mathrm{C} 4$ landareek ${ }^{12} \mathrm{C}$ isotopo arina (2. irudia). Hau da, C4 landareek C3 landareek baino $\delta^{13} \mathrm{C}$ balio aberatsagoak erakusten dituzte ( $\mathrm{C} 4$ landareen $\delta^{13} \mathrm{C}$ balioak \%o -13 eta -27 artean daude) (2. irudia) [17]. Horregatik, karbono-isotopo arrazoiak C3 eta C4 landare moten arteko bereizketa ahalbidetzen du, eta, beraz, gizakiak kontsumitutako elikagaien jatorria bereiz daiteke. Ekosistema lurtarreko elikagaiak, oro har C3 taldeko landareak dira, Europako ipar-mendebaldean eta Penintsula Iberiarreko iparraldeko eskualde epeletako eremuetan aurkitzen diren zuhaitz eta zuhaixka gehienak. Zereal mota gehienak ere C3 motatako landareak dira, garia (Tritium), garagarra (Hordeum vulgare) eta oloa, esate baterako. C4 landareak ingurune lehorragoetan hasten dira: haien artean, 
artatxikia (Pennisetum), artoa (Zea mays) eta azukre kanabera (Succharum officinarum) daude [18].

FOTOSINTESIAREN ARABERA

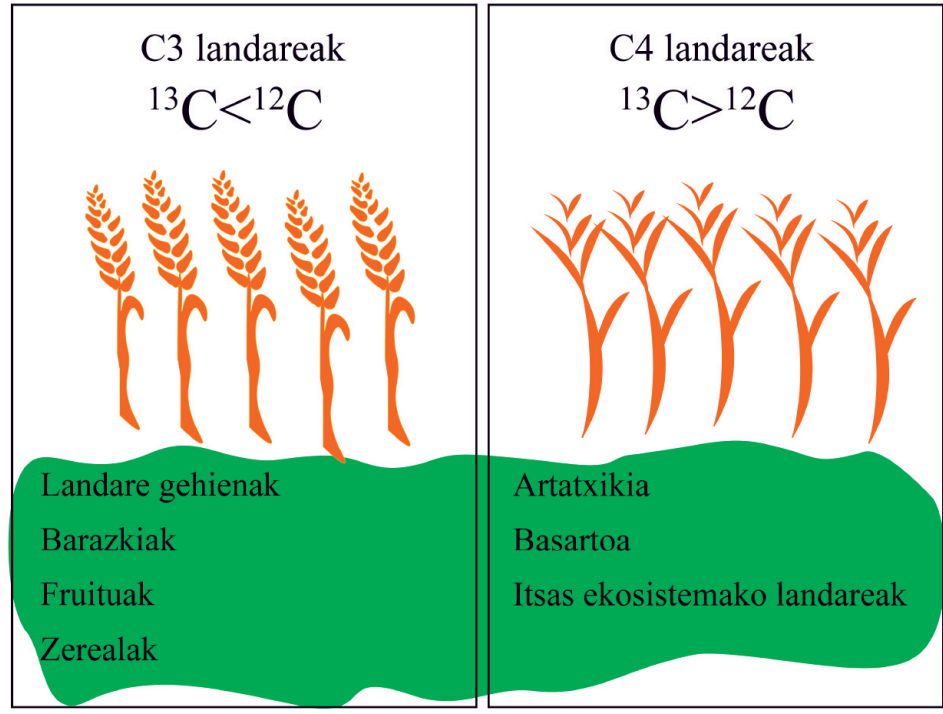

2. irudia. Fotosintesiaren araberako $\mathrm{C} 3$ eta $\mathrm{C} 4$ landare motak eta fotosintesian nahiago duten karbono-isotopoa.

Nahiz eta Iberiar Penintsulan C3 landareak gailendu, aspalditik nekazariek C4 landareak ere landatzen zituzten. Erdi Aroan zehar Iberiar Penintsulan ohikoa zen C3 eta C4 landareak jatea. Hala ere, XI. mendetik aurrera populazioak gora egin zuen ikaragarri, gari defizita zegoen, eta horrek C4 landareak ereitea areagotu zuen, batez ere artatxikia. Izan ere, artatxikia Ipar Penintsulan diren baldintzak klimatikoetarako aproposagoa da. Aldaera hau erraz ikus daiteke Momoitioko San Juan aztarnategiko giza aztarnen karbono isotopo-konposizioen azterketan (3. irudia). 3. irudian ikus daitekeen modura, IX-XI. mendeetan gizaki aztarnen $\delta^{13} \mathrm{C}$ balioak $-19,0$ eta $-14,3$ artekoak dira, tarte zabala osatzen dutelarik, eta, aldiz, XII. mendean, balioak $-18,5$ eta $-14,3$ bitartekoak dira. Nahiz eta tarteak antzekoak izan, IX-XI. mendeetako biztanleriaren $\delta^{13} \mathrm{C}$-aren batezbesteko balioa XII. mendekoa baino negatiboagoa da, C3 landareen kontsumo nabariagoa markatuz, eta, aldiz, XII. mendean, C4 landareen kontsumoa gailentzen da.

Bestetik, karbono-isotopo egonkorrak elikagai lurtar eta itsastarretan oinarritutako dietak desberdintzeko erabiltzen dira. Itsas landare guztiak $\mathrm{C} 4$ motako landareak dira; batezbesteko $\delta^{13} \mathrm{C}$ balioa \%o7,5 ingurukoa dute, lehorrekoak baino nabarmen altuagoa $[19,20]$. 
Iranzu Guede, Ainhoa Alonso-Olazabal, Maria Cruz,Zuluaga, Luis Angel Ortega

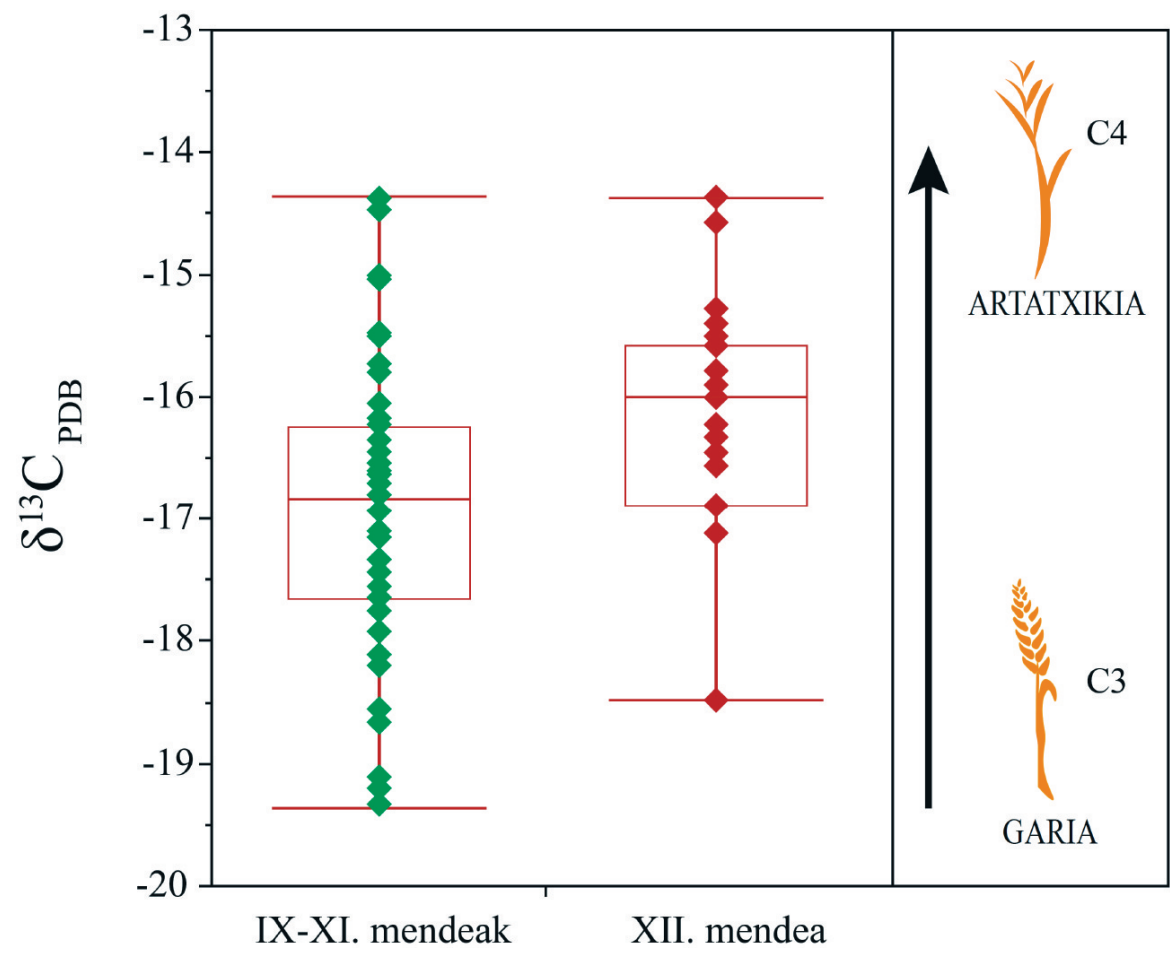

3. irudia. IX-XI. mendeetako eta XII. mendeko Momoitioko San Juaneko biztanleriaren $\delta^{13} \mathrm{C}$ balioen kaxa-diagramak eta aldameneko irudian gariaren eta artatxikiaren $\delta^{13} \mathrm{C}$ balioak.

\subsubsection{Nitrogeno-isotopo egonkorrak}

Elikadura ikerketetan nitrogeno isotopo-arrazoiak animalia-proteinen sarrera islatzen du, eta proteinaren jatorrizko animaliaren maila trofikoari buruzko informazioa lortzeko ere erabiltzen da [21-23].

Nitrogeno isotopo-arrazoiak $\delta^{15} \mathrm{~N}$ balio gisa adierazten dira (\%o) eta erabiltzen den estandarra atmosferako nitrogenoa da (AIR) [24].

$$
\delta^{15} \mathrm{~N}(\%)=\left[\left({ }^{15} \mathrm{~N} /{ }^{14} \mathrm{~N}_{\text {lagina }}{ }^{15} \mathrm{~N} /{ }^{14} \mathrm{~N}_{\text {AIR }}\right)-1\right] \times 1.000
$$

Ekosistema lurtar eta itsastarrean azaltzen diren $\delta^{15} \mathrm{~N}$ balioak nabarmenki desberdinak dira, ekosistema lurtarretan itsastarretan baino baxuagoak dira eta $\delta^{15} \mathrm{~N}$ balioak maila trofikoa handitzean aldatzen dira (4. irudia). Ekosistema guztietan elikagaietatik gorputzeko ehunetara pasatzean, kontsumitzailearen $\delta^{15} \mathrm{~N}$ balioak maila trofikoa handitu ahala \%o 2-5 bitartean (batezbesteko \%o 3) aberasten dira [25]. 


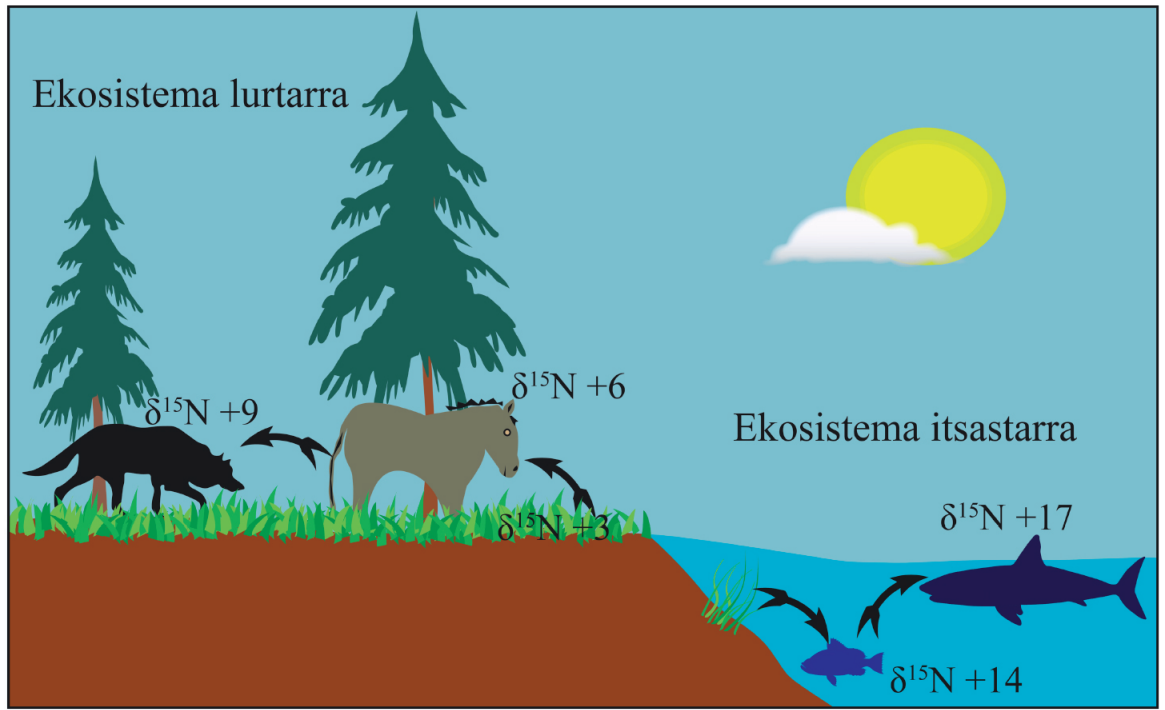

4. irudia. Ingurune lurtarretako eta itsastarreko animalien $\delta^{15} \mathrm{~N}$ balioak eta $\delta^{15} \mathrm{~N}$ balio altuagoak maila trofikoa handitu ahala.
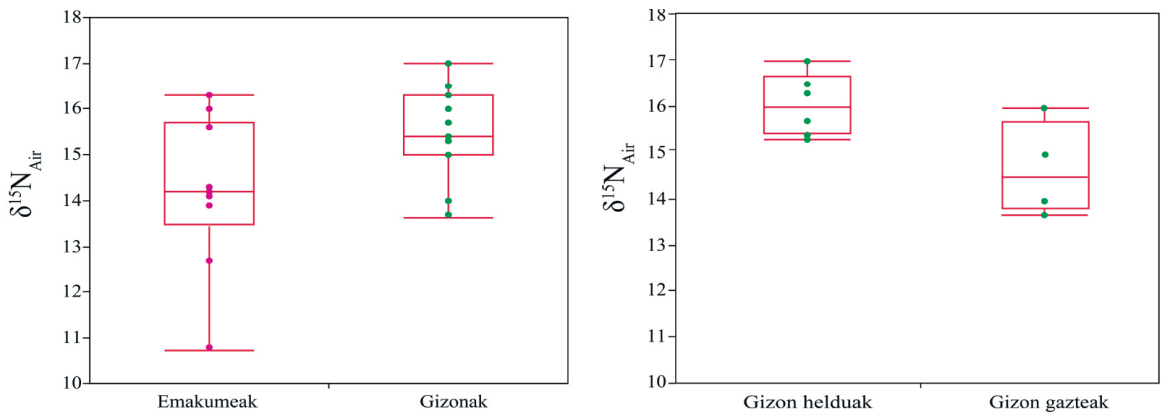

5. irudia. Tausteko biztanleriaren sexuaren eta adinaren araberako $\delta^{15} \mathrm{~N}$ balioen kaxa-diagramak.

Aztarnategi bateko gizakien elikadura aztertzean $\delta^{15} \mathrm{~N}$ balioetan aldakortasunak izateak adierazten du elikadura ezberdinak daudela. Aldakortasun horiek jaten diren elikagaiekin eta haien kate trofikoan duten mailarekin loturik daude. Honen adibide ona Tauste aztarnategiko gizakien nitrogeno-isotopo arrazoiak aztertzean ikusten da (5. irudia). Tausteko gizakien $\delta^{15} \mathrm{~N}$ balio ezberdinek elikadura ezberdintasunak zeudela argi adierazten dute; ezberdintasun horiek sexuaren eta adinaren araberakoak dira. Gizon nagusienen $\delta^{15} \mathrm{~N}$ balioak $\left(\delta^{15} \mathrm{~N}=\%\right.$ o $\left.15,5 \pm 1\right)$ emakume 
Iranzu Guede, Ainhoa Alonso-Olazabal, Maria Cruz Zuluaga, Luis Angel Ortega

eta gazteenak baino altuagoak dira $\left(\delta^{15} \mathrm{~N}=\%\right.$ o $14,6 \pm 1,2$ emakumeetan eta $\%$ 14,8 \pm 1 gizon gazteetan), eta elikadurari dagokionez, maila trofiko altuagoan dauden elikagaiak jaten zituztela adierazten dute. Alegia, adierazten dute gizon helduek emakume eta gazteek baino animalietatik eratorritako elikagai gehiago jaten zutela.

Horrez gain, nitrogeno-isotopo egonkorraren analisia ere erabil daiteke edoskitzetik bularra kentzeko trantsizio garaia behatzeko. Edoskitzean, umeak amaren esnea kontsumitzen duenez elikagai-katean gorago kokatzen dira eta umearen ehunetako nitrogeno isotopo-arrazoiak altuagoak dira. Umearen $\delta^{15} \mathrm{~N}$ balioak amarenarekiko \%o 2-3-ko aberastea pairatzen du [26]. Amaren bularra beste elikagaiez ordezten denean, umearen ehunen nitrogeno arrazoia jaisten da eta amarenarekin eta bizi den populazio horretako beste helduenarekin parekatzen da.

Horren adibide bat Las Gobas aztarnategian ikusten da: han, ume ugarik gizaki gazte eta helduek baino $\delta^{15} \mathrm{~N}$ balio altuagoak dituzte (6. irudia). Kasu honetan, umeen $\delta^{15} \mathrm{~N}$ balio altuagoak, aurrerago aipatu den modura, edoskitzeari lotuta daude. Aztarnategi horretan nitrogeno-arrazoi baxuak azaltzen dituzten umeak ere badira, amaren bularra uztean eta elikagaiak hartzean $\delta^{15} \mathrm{~N}$ balioak jaisten direlako (kolore arrosadun eremua).

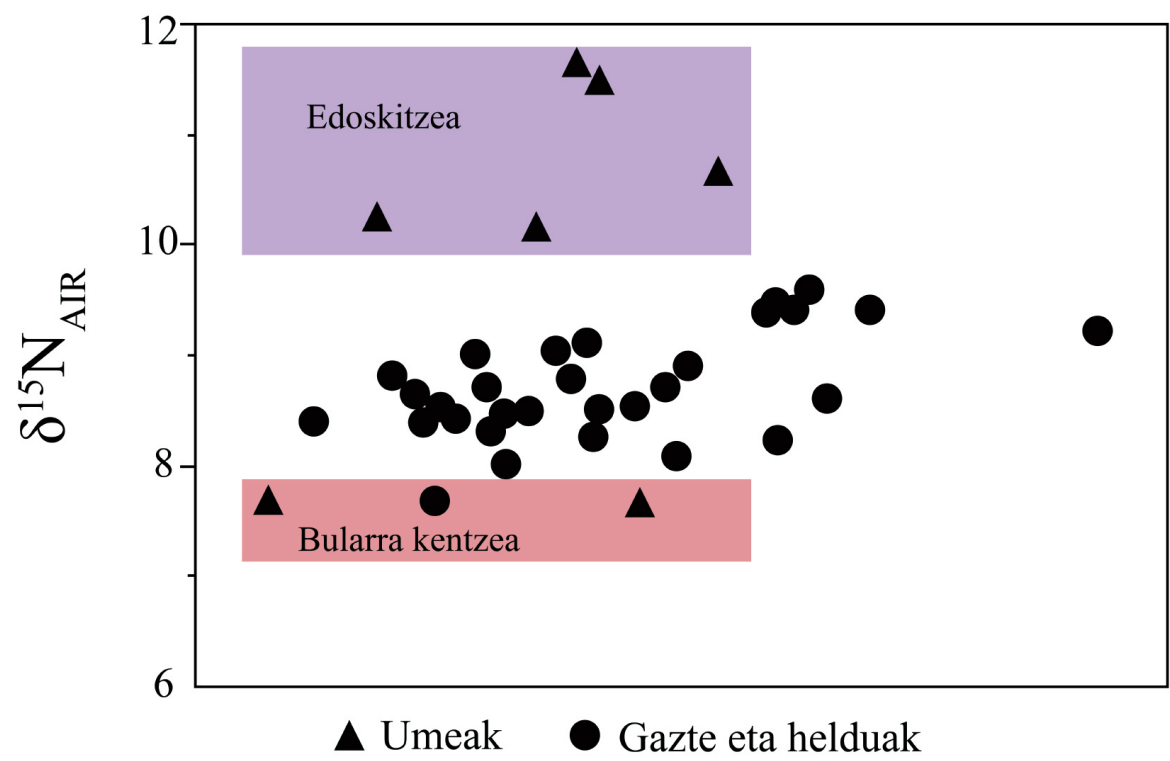

6. irudia. Las Gobas aztarnategiko $\delta^{15} \mathrm{~N}$ balioak; kolore ezberdinez adierazita daude bularra hartzen duten umeen balio altuak (lila koloreko eremua) eta bularesnez eta beste elikagaiez elikatzen direnen umeen balioak (arrosa koloreko eremua). 
Hala ere, landare eta animalien $\delta^{15} \mathrm{~N}$ balioen aldakortasuna azaltzen duten beste arrazoi batzuk ere badaude: esate baterako, ingurumenaren baldintza naturalak, hala nola, gazitasuna eta idortasuna [27]. Baldintza antropikoek $\delta^{15} \mathrm{~N}$ balioak ere alda ditzakete, lurzorua ongarritzea, besteak beste [28]. Simaurra ongarri gisa erabiltzeak $\delta^{15} \mathrm{~N}$-ren balioen aberastea eragiten $\mathrm{du}$, eta ondorioz lurzoru ongarritu horretako elikagaiekin elikatutako izakien $\delta^{15} \mathrm{~N}$ balioak ere altuagoak izango dira. Beraz, isotopo-konposizioa ingurunearen arabera alda daitekeenez, beharrezkoa da aztertzen ari garen aztarnen tokiko isotopo-osaera ezartzea. Horretarako, ikertzen ari den aztarnategian, komenigarria da aurkitutako fauna eta landare arrastoen analisi isotopikoak ere egitea.

Tausteko aztarnategiko gizakien $\delta^{15} \mathrm{~N}$ balioak espero zitekeena baino altuagoak izan dira. Erdi Aroko aztarnategi bateko gizakien elikadura orojalea zela kontsideratzen bada, $\delta^{15} \mathrm{~N}$ balioak ez lirateke $+10 \%$ inguru baino altuagoak izan beharko, baina, oro har, Tausteko aztarnategiko aztarnen batezbesteko balioa $+15 \%$ o da, eta elikaduraren funtsa arraina izan zitekeela pentsa daiteke (7. irudia).

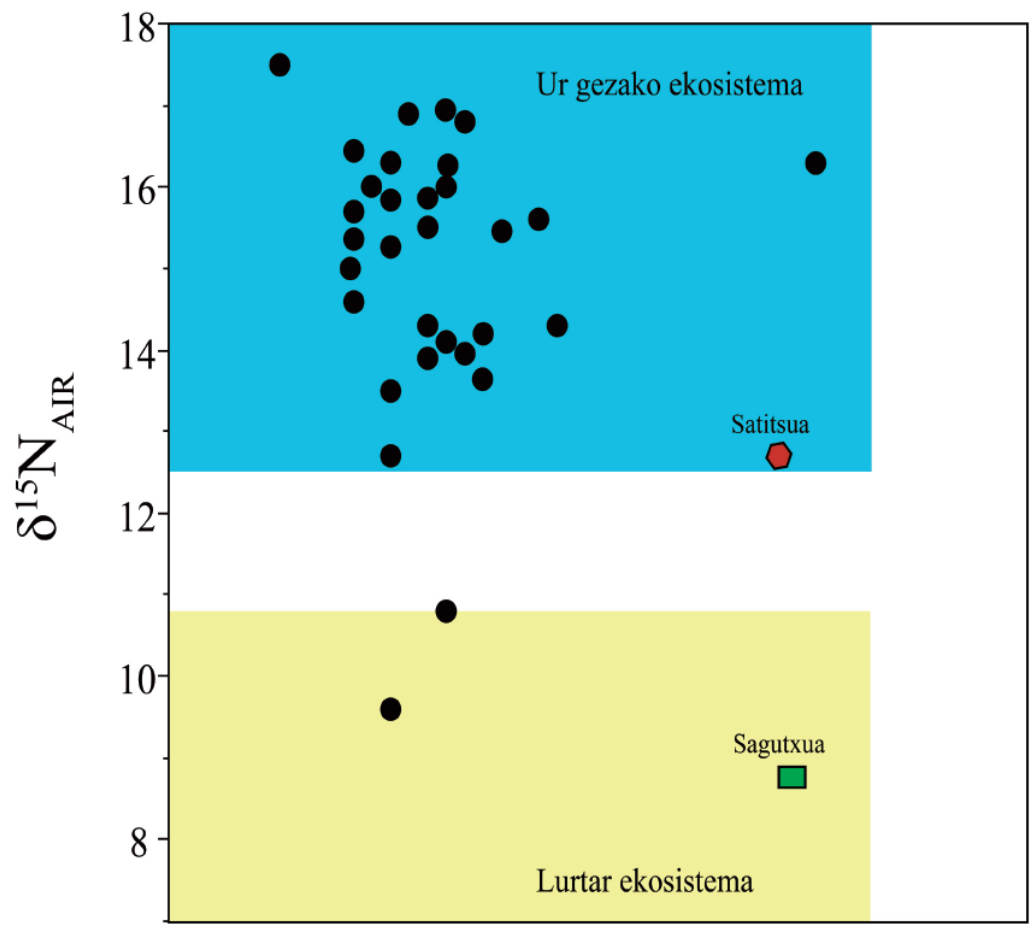

7. irudia. Tauste aztarnategiko gizakien eta faunaren (sagutxo eta satitsua) $\delta^{15} \mathrm{~N}$ balioak. Koloreztatuta, horiz, lurtar ekosistemen $\delta^{15} \mathrm{~N}$ balioak, eta urdinez, ur gezetakoak. 


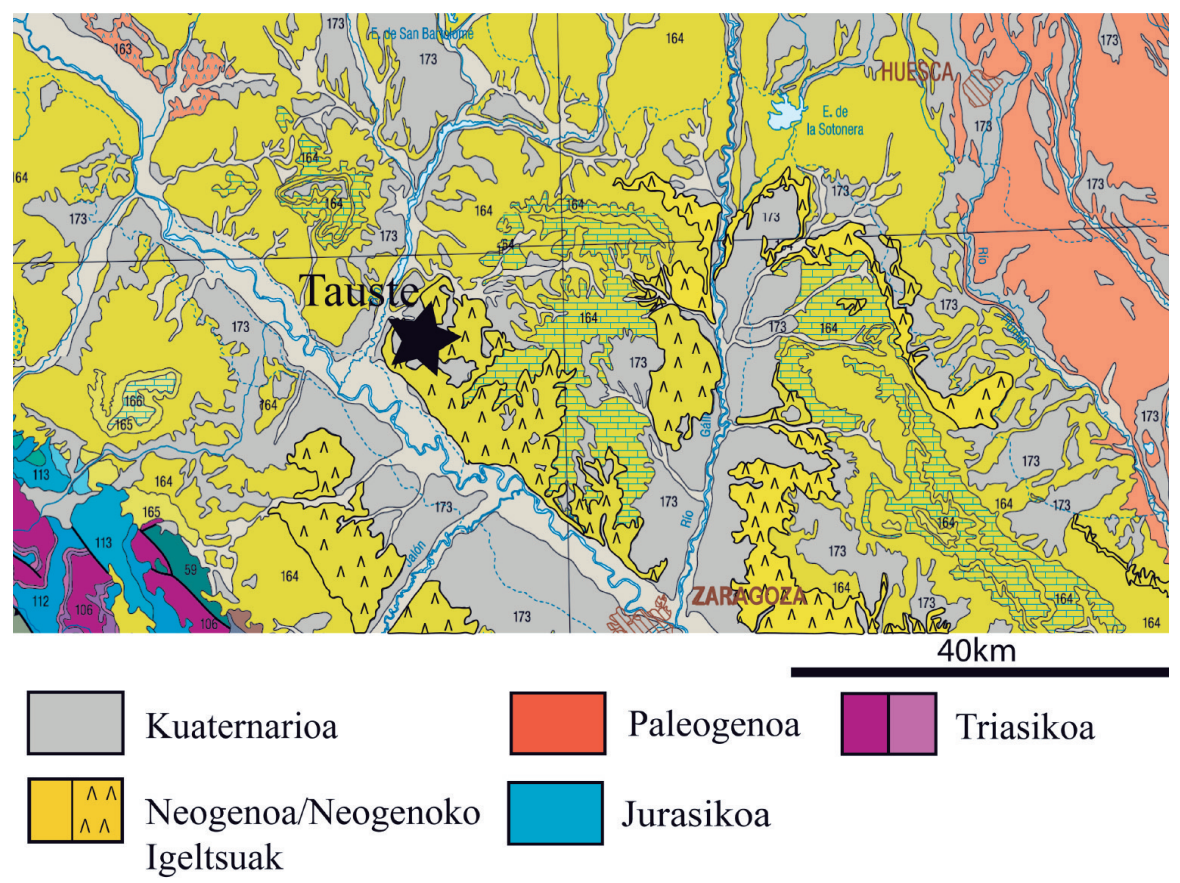

8. irudia. Tauste aztarnategiko kokapen geologikoa Neogenoko igeltsu eta gatzdun materialetan [29].

Baina Islamiar munduan ez dago elikaduraren oinarria arrainen kontsumoa zela baieztatzen duen garai hartako dokumenturik, eta hau dela eta, dieta orojalea zutela kontsideratu da. Elikadurari buruzko afera hau argitzeko asmoz, Tauste inguruko gaur eguneko ornodun txikiak - sagu eta satitsua - analizatu ziren, eskualdeko $\delta^{15} \mathrm{~N}$ balioak ezagutzeko asmotan. Sagutxoaren nitrogeno-isotopo balioa, elikadura belarjale baten balioen isla izango litzateke, eta satitsuarenak, aldiz, haragijale batenak. Aipatzekoa da ornodun txiki hauen $\delta^{15} \mathrm{~N}$ emaitzak ere altuak direla, animalia hauen elikadurari loturiko $\delta^{15} \mathrm{~N}$ balioak baino altuagoak, eta gizakiek zutenen antzekoak. Beraz, gizakietan neurtutako $\delta^{15} \mathrm{~N}$ balio altuak ez daudenez zuzenean elikadurari lotuta, bestelako baldintzei begiratu behar zaie balio hauen arrazoia aurkitzeko. Horrela, bi aukera kontuan hartu ziren: alde batetik, $\delta^{15} \mathrm{~N}$ balioak eskualdeko geologia-baldintzei loturik egongo liratekeela. Gazitasun altua izateak $\delta^{15} \mathrm{~N}$ balioetan eragina du, balioak aberastuz. Izan ere, Tausteko aztarnategia Neogenoko igeltsuetan kokatzen denez (8. irudia), igeltsua eta gatzak disolbatzean, inguruko ur eta lurzoru gazien $\delta^{15} \mathrm{~N}$ balioak ohikoak baino altuagoak izaten dira. Bestetik, $\delta^{15} \mathrm{~N}$ altuak ongarritutako lurzoruekin erlazionaturik egon daitezke. Erdi Aroan jadanik erabiltzen zen simaurra ongarri modura, eta horrek, $\delta^{15} \mathrm{~N}$ balioen aberastea 
ere eragin zezakeen. Ondorioz, lurzoru ongarritu horretako elikagaiekin elikatutako izakien $\delta^{15} \mathrm{~N}$ balioak altuagoak izango ziren. Hala eta guztiz ere, ezin daiteke baztertu arrainen kontsumoa, nahiz eta kantitate xumean izango litzatekeen.

Ohikoa da dieta- eta elikadura-ikerketetan karbono- eta nitrogeno-isotopoen emaitzak batera azaltzea. Karbono eta nitrogeno isotopo-arrazoiak elkarrekin maiz erabiltzen dira elikaduraren inguruko galderak argitzeko (9. irudia), horien artean maila trofikoaren kokapena eta elikagai ezberdinen interakzioak modu integratu batean aztertzeko eta interpretazio sendoagoak lortzeko.

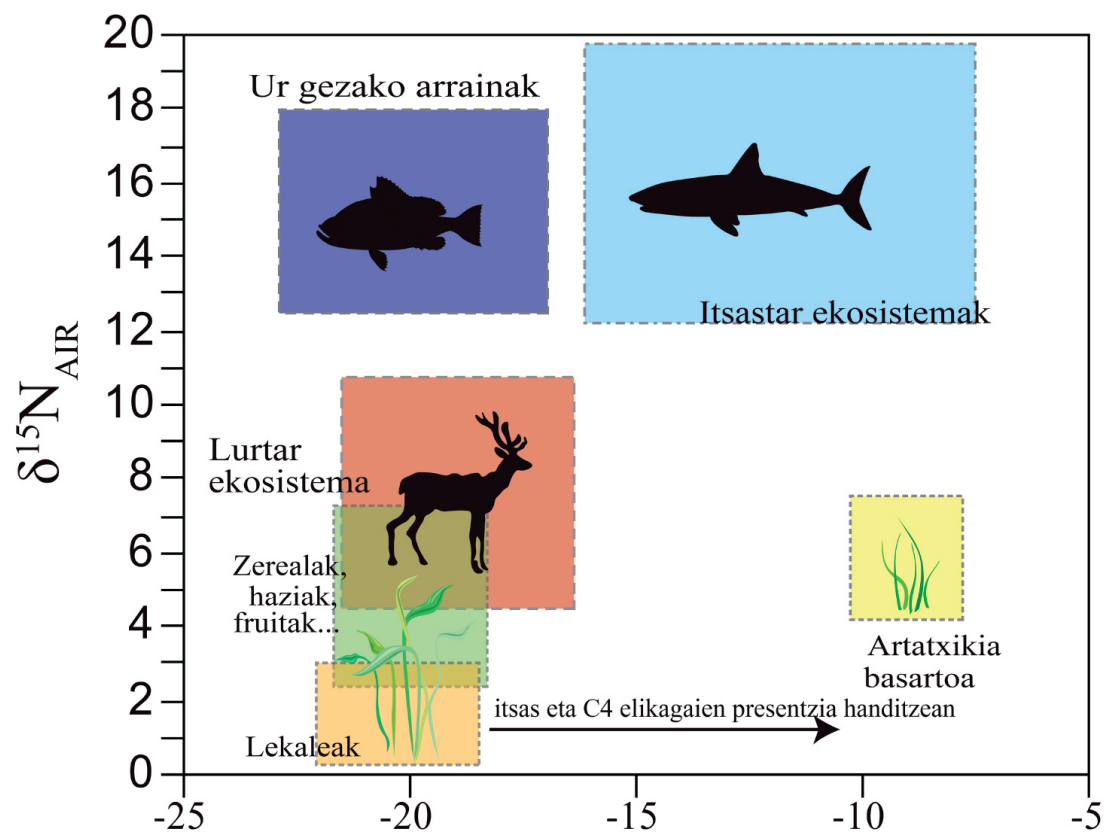

9. irudia. Ekosistema, elikagai eta maila trofiko ezberdinetako $\delta^{13} \mathrm{C}$ eta $\delta^{15} \mathrm{~N}$ balioak.

\subsection{Oxigeno-isotopoak}

Oxigeno-isotopoen erlazioa baliagarria da iraganeko eta gaur eguneko biztanleriaren jatorriari buruzko informazioa lortzeko [30-32]. Era berean, diziplina ezberdinetako adituek oxigeno-isotopoak erabiltzen dituzte espezie desberdinetan paleoklima berreraikitzeko [33, 34], animalien migrazioen eta artzaintzaren ereduak ezagutzeko $[35,36]$, eta animalia eta landareen jatorri geografikoa ezagutzeko [38, 39]. 
Iranzu Guede, Ainhoa Alonso-Olazabal, Maria Cruz Zuluaga, Luis Angel Ortega

Oxigeno-isotopo balioak $\delta^{18} \mathrm{O}$ modura adierazten dira, eta erabiltzen den estandarra Vienako itsas uraren batazbestekoa (Vienna Standard Mean Ocean Water, VSMOW) da; ekuazioa honako hau da:

$$
\delta^{18} \mathrm{O}(\%)=\left[\left({ }^{18} \mathrm{O} /{ }^{16} \mathrm{O}_{\text {lagina }} /{ }^{18} \mathrm{O} /{ }^{16} \mathrm{O}_{\text {VSMOW }}\right)-1\right] \times 1.000
$$

Izaki baten hortz eta hezurretako oxigenoaren isotopo-sinadura edaten den uren bidez barneratzen da, alegia gizakien ehunetan neurtutako oxigeno-isotopo erlazioak edandako uraren konposizio isotopikoa islatzen du, eta edaten den uraren konposizioa lekuko airearen tenperaturaren eta kokapen geografikoaren araberakoa izango da, euriaren edo lurrazpiko uren araberakoa, hain zuzen ere. Egiaztatuta dago gizakia bizi den lekuko urteko batezbestekoaren euriaren $\delta^{18} \mathrm{O}_{\mathrm{w}}$-aren eta giza eskeletoaren hezurren fosfatoaren $\delta^{18} \mathrm{O}_{\mathrm{p}}$-aren artean erlazio zuzena dagoela [39, 30]. Hau da, hortz eta hezurretako bioapatitoaren fosfatoan $\left(\delta^{18} \mathrm{O}_{\mathrm{p}}\right)$ eta karbonatoetan neurtzen diren oxigeno-isotopoen arrazoiak, gizakien mugikortasun-trazatzaile modura erabiltzen dira, balio horiek uraren oxigeno-isotopo $\left(\delta^{18} \mathrm{O}_{\mathrm{w}}\right)$ balio baliokideetara bihurtuz literaturan aurkitzen diren ekuazio-bihurketa espezifikoen bidez [39, 40]. Gizakietan neurtuak diren balioak IAEA/WISER datu-basean azaltzen direnekin [41] alderatzen dira (10. irudia). IAEA/ WISER datu-basea ibaiko uren $\delta^{18} \mathrm{O}$ eta prezipitazio uren $\delta^{18} \mathrm{O}$ balioen mapak dira, eta eskuragarri daude Interneten [41].

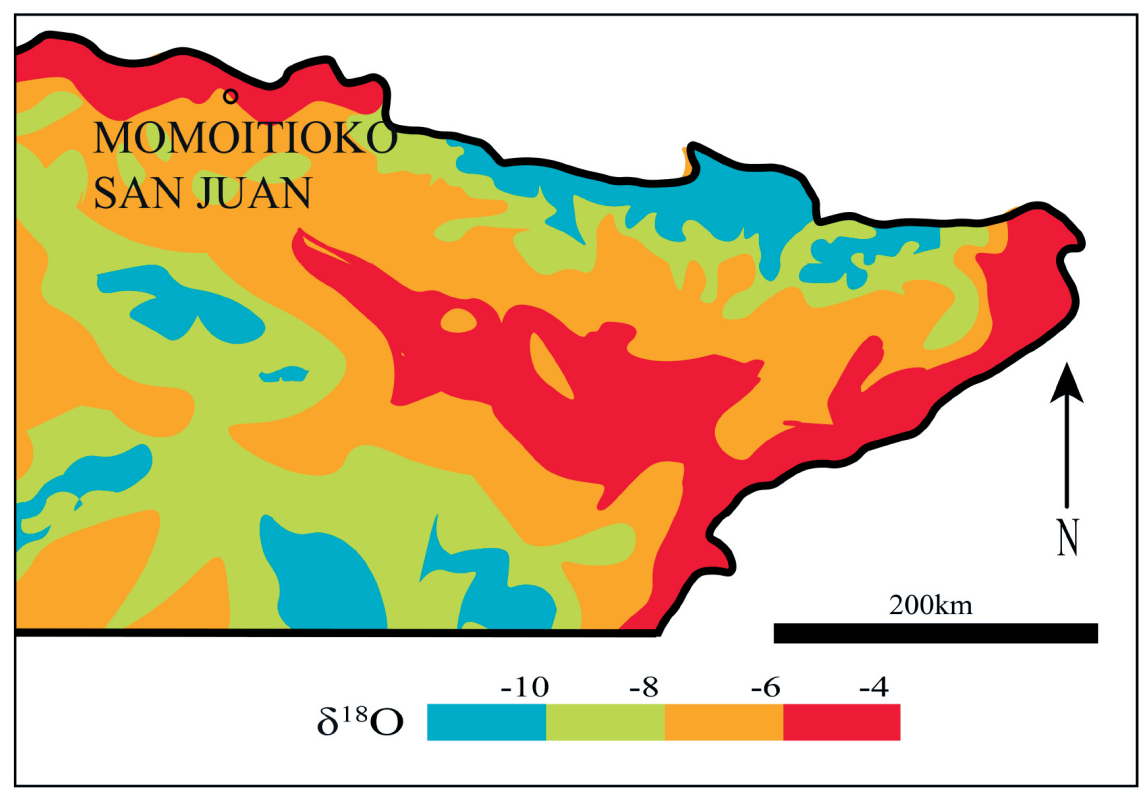

10. irudia. Momoitioko San Juan aztarnategiaren kokapena Ipar ekialdeko Iberiar Penintsulako uren $\delta^{18} \mathrm{O}$ balioen mapan $[41,42]$. 
Esan bezala, gizakien fosfato biogenikoaren balioak edateko uraren balioetara eraldatu behar dira lehenik, eta ondoren, balio horiek erabili datu basekoekin alderatzeko, horrela 11. irudian ikus daiteke Momoitioko San Juan aztarnategiko gizakiek edandako uren $\delta^{18} \mathrm{O}$ balioak eta eskualdeko uren $\delta^{18} \mathrm{O}_{\mathrm{w}}$ balioak kolore grisez mugatuta. Argi antzeman daiteke biztanleriaren gehiengoaren balioak eskualdeko $\delta^{18} \mathrm{O}_{\mathrm{w}}$ balioen tartean daudela, kasu batzuk izan ezik. Eskualdeko $\delta^{18} \mathrm{O}$ balioen eremutik kanpo gelditzen diren gizakiek, batzuek eskualdekoek baino balio altuagoak erakusten dituztenez, jatorri eskualdea kostaldetik hurbilago edota klima epelago batean kokatuko lirateke. Beste batzuek, aldiz, eskualdekoek baino balio baxuagoak azaltzen dituztenek, klima hotzagoko edota garaiera altuagoko eskualde batean izango lukete jatorria.

Estrontzio- eta oxigeno-isotopoak bi sistema isotopiko independente dira, baina biak konbinatuz gizabanako baten jatorrizko eremu posibleari buruzko informazioa ematen dute, eta, beraz, mugikortasun-ereduei buruzko informazioa ere bai [43]. Europan era honetako ikerketa-lan ugari ditugu: Neanderthalen migrazioak [16] eta Irlanda eta Eskoziako bikingoen kolonien azterketak [44] analizatu dituztenak, besteak beste.

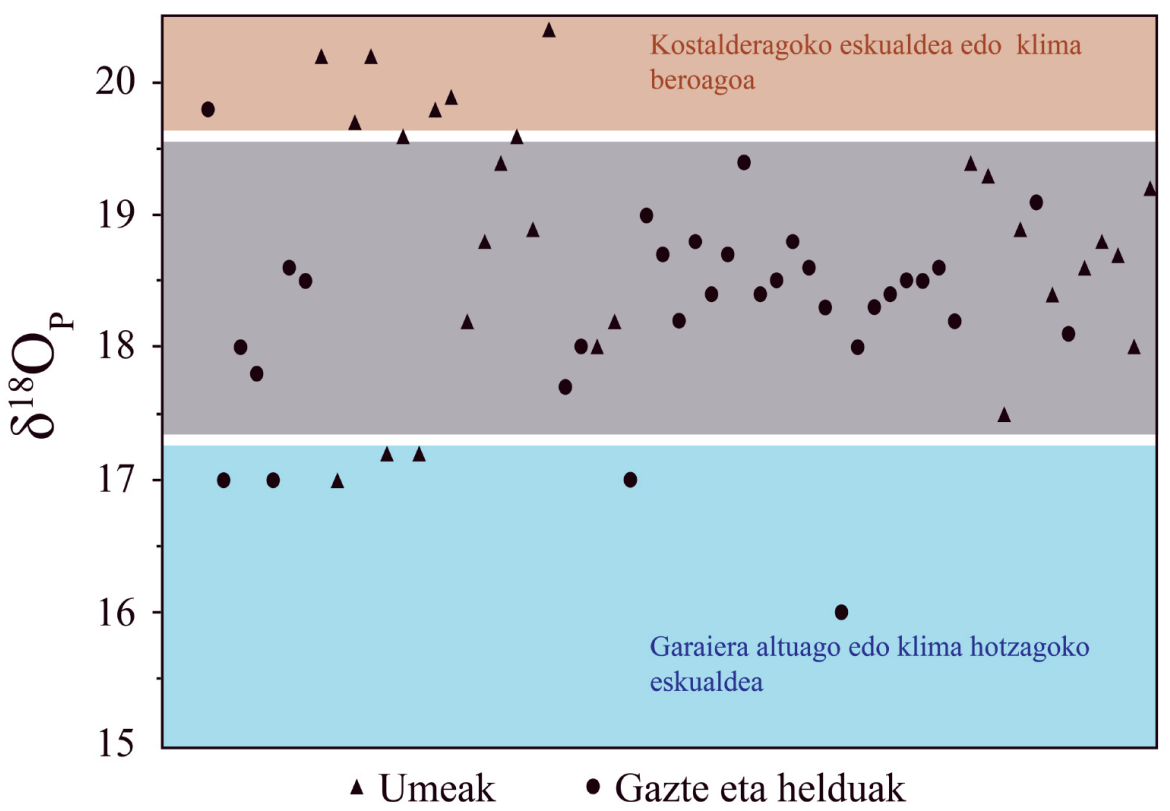

11. irudia. Momoitioko San Juan aztarnategiko gizakien (ume, gazte eta helduen) $\delta^{18} \mathrm{O}_{\mathrm{p}}$ balioak. Eremu grisak aztarnategiko inguruko $\delta^{18} \mathrm{O}_{\mathrm{w}}$ konposizioa mugatzen du, eremu urdinak eskualde hotzago edo garaiera altuago bateko isotopo-konposizioa eta eremu laranjak kostaldekoagoa edo epelagoa den eskualdeko isotopo-konposizioa. 
Iranzu Guede, Ainhoa Alonso-Olazabal, Maria Cruz Zuluaga, Luis Angel Ortega

\subsection{Estrontzio-isotopoak}

Estrontzioa arroka, ur, lurzoru, landare eta animalietan kontzentrazio desberdinetan azaltzen den elementua da. Estrontzioak lau isotopo egonkor ditu ${ }^{84} \mathrm{Sr}(\% 0,56),{ }^{86} \mathrm{Sr}\left(\%\right.$ 9,86), ${ }^{87} \mathrm{Sr}(\% 7,0)$ eta ${ }^{88} \mathrm{Sr}(\%$ 82,58). Isotopo horietatik bat, ${ }^{87} \mathrm{Sr}$, erradiogenikoa da eta ${ }^{87} \mathrm{Rb}$ isotopo erradioaktiboaren desintegraziotik eratorria da. Nahiz eta maila trofikoaren arabera organismoek duten Sr kontzentrazioa aldakorra izan, konposizio isotopikoa ez da aldakorra, alegia ez du frakzionaziorik pairatzen [45]. Datuak ${ }^{87} \mathrm{Sr} /{ }^{86} \mathrm{Sr}$ modura adierazten dira, eta ${ }^{87} \mathrm{Sr} /{ }^{86} \mathrm{Sr}$ arrazoia arrokaren adin eta arrokaren $\mathrm{Rb} / \mathrm{Sr}$ konposizioaren araberakoa da [45]. Horrela, substratu geologiko ezberdinek ${ }^{87} \mathrm{Sr} /{ }^{86} \mathrm{Sr}$ arrazoi desberdinak dituzte aurkezten dituzten mineralen arabera eta adin geologikoaren arabera. Isotopo hauek ez dutenez frakzionaziorik pairatzen, arrokaren meteorizazioak Sr askatzen du mineraletatik, eta lurzoruko poroetako uren bidez barreiatzen da eta ekosisteman sartzen da. Ekosistema batean, beraz, lurzoru eta landareetan uzten duen seinale isotopikoa, animalia eta gizakietan islatuko da [27]. Beraz, gizakien hezurretako eta hortzetako fase mineralen ${ }^{87} \mathrm{Sr} /{ }^{86} \mathrm{Sr}$ arrazoia, gizakia bizi deneko eskualdeko geologiak baldintzatzen du.

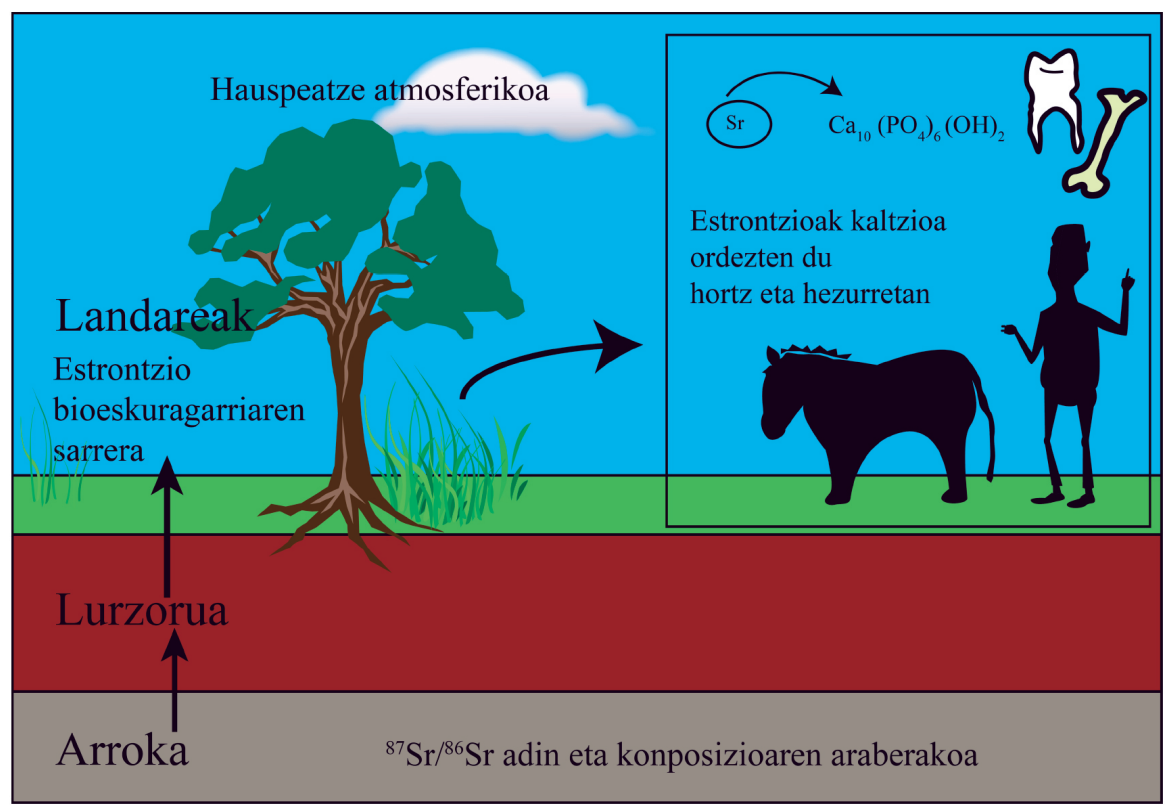

12. irudia. Estrontzio-isotopoen ziklo geokimikoa.

Izakiek estrontzioa ur eta elikagaien bitartez eskuratzen dute. Estrontzioa, hezur eta hortzetako esmaltearen hidroxiapatitoaren egitura mineralean kokatzen da, kaltzioa ordezkatuz (12. irudia). Gizaki ehunetako 
${ }^{87} \mathrm{Sr} /{ }^{86} \mathrm{Sr}$ arrazoiak kontsumitzen diren ur, landare eta animalien ${ }^{87} \mathrm{Sr} /{ }^{86} \mathrm{Sr}$ konposizioa islatzen dute eta hauek, eremu horretako arrokena islatuko dute hain zuzen ere. Esmaltea haurtzaroan eratzen da, eta haren konposizio isotopikoa ez da aldatzen bizitzan zehar [46]. Aldiz, hezurretako estrontzio arrazoia izakiaren bizitzan zehar berrorekatuz doa etengabe [47]. Kontuan hartuz garai hartako gizakiek soilik produktu lokalak jan eta edaten zituztela, esmalteko ${ }^{87} \mathrm{Sr} /{ }^{86} \mathrm{Sr}$ arrazoiak haurtzaroko etapan zeharreko elikagaien isotopo-konposizioa islatuko du, eta, beraz, haurtzaroan bizi izan ziren eskualdearena. Aldiz, hezurretako ${ }^{87} \mathrm{Sr} /{ }^{86} \mathrm{Sr}$ erlazioak heldua zen garaiko dieta eta, aldi berean, bizi izan zeneko eskualdearen geologia islatuko ditu.

Eskualdeko ${ }^{87} \mathrm{Sr} /{ }^{86} \mathrm{Sr}$ arrazoiaren ezagutza beharrezkoa da eta horretarako material ezberdinak erabil daitezke (ura, lurzorua, landaredia eta fauna), baina bakoitzak bere abantailak eta desabantailak ditu. Esate baterako, gaur egungo materialak kutsatuak egon daitezke gizakiaren ekintzen ondorioz; aldiz, fauna arkeologikoa eta, bereziki, mikrofauna eta barraskiloak egokiagoak dira, ez direlako asko urruntzen bizi diren tokitik; horrela, horiek analizatuz, eskualdeko ${ }^{87} \mathrm{Sr} /{ }^{86} \mathrm{Sr}$ konposizioaren informazioa lortzen da.

Beraz, gizakiek ${ }^{87} \mathrm{Sr} /{ }^{86} \mathrm{Sr}$ arrazoia bertako ingurunetik jaraunsten dutenez, bizileku-mugikortasun eta gizaki edo populazioen bizimodua ebalua daiteke estrontzio-isotopo sinadura aztertuz eskeletoko ehunetan. Besteak beste, Tausteko aztarnategian gizakien jatorriari buruzko informazio lortzeko ${ }^{87} \mathrm{Sr} /{ }^{86} \mathrm{Sr}$ analisiak egin ziren. Lehenik, eskualdeko ${ }^{87} \mathrm{Sr} /{ }^{86} \mathrm{Sr}$ ezagutzeko lurzoru eta ibaiko uren laginak analizatu ziren. 13. irudian ikus daiteke Tauste eskualdeko ${ }^{87} \mathrm{Sr} /{ }^{86} \mathrm{Sr}$ konposizioa kolore griseko eremuaren bidez irudikatua. Tausteko aztarnategia geologia nahiko homogeneodun eremu zabala betetzen duen Neogenoko materialetan kokatzen da (8. irudia) eta homogeneizatze geologiko honek eskualdeko isotopo-konposizioa nahiko mugatua izatea baldintzatzen du. Ondoren ${ }^{87} \mathrm{Sr} /{ }^{86} \mathrm{Sr}$ konposizioa gizakienekin alderatzen da, eta horretarako, gizakien esmalteaz gain hezurrak ere analizatu dira. Esmalteak umetan bizitako ${ }^{87} \mathrm{Sr} /{ }^{86} \mathrm{Sr}$ konposizioaren isla dira, eta, aldiz, hezurrak gizakia hil aurreko urteetako estrontzio isotopo-konposizioa azaltzen du. Horrela, bizitoki-aldaketarik izan bada, erraz ikusi ahalko litzateke.

Tausteko gizaki gehienen ${ }^{87} \mathrm{Sr} /{ }^{86} \mathrm{Sr}$ arrazoiak eskualdeko isotopo-konposizioaren tartean kokatzen dira (13. irudia), han bertan jaiotakoak direla adieraziz, edo, gutxienez, jaio zireneko tokiaren eta hil zireneko tokiaren ${ }^{87} \mathrm{Sr} /{ }^{86} \mathrm{Sr}$ konposizioa berdina zela. Soilik T-24 laginari dagokion gizakiak azaltzen du esmaltean bestelakoa den ${ }^{87} \mathrm{Sr} /{ }^{86} \mathrm{Sr}$ konposizioa, kanpotarra dela adieraziz. Aipagarria da analizatutako hezurren artean T-32 gizakiak eskualdekoa ez den ${ }^{87} \mathrm{Sr} /{ }^{86} \mathrm{Sr}$ konposizioa azaltzen duela, esmalteak, ordea, lekuko konposizioa azaltzen du. Horrek adierazten digu Tausten jaioa zela, eta nagusitan bertatik alde egin zuela, hil aurretik berriro Tauste herrira bueltatzeko. Era berean, hezurretako ${ }^{87} \mathrm{Sr} /{ }^{86} \mathrm{Sr}$ konposizioa tokiko isotopo- 
Iranzu Guede, Ainhoa Alonso-Olazabal, Maria Cruz Zuluaga, Luis Angel Ortega

konposizioarekin birrorekatzeko bost urte behar dituenez, ondoriozta daiteke bost urte baino gutxiago egon zela Tausten bizitzen hil aurretik.

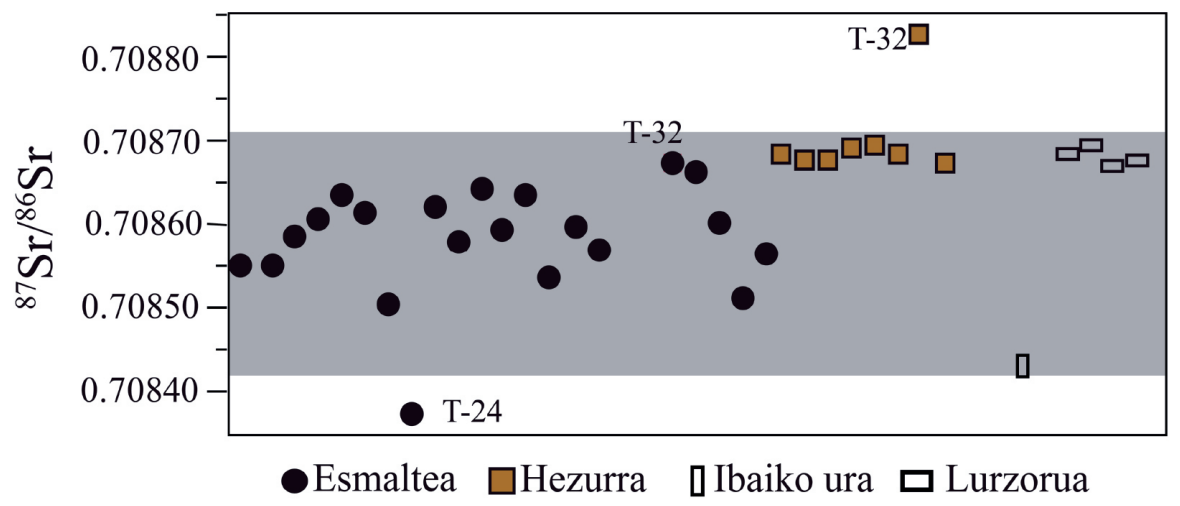

13. irudia. Tauste aztarnategiko gizakien aztarna, lurzoru eta ibaiko uren ${ }^{87} \mathrm{Sr} /{ }^{86} \mathrm{Sr}$ balioak. Eremu grisak eskualdeko ${ }^{87} \mathrm{Sr} /{ }^{86} \mathrm{Sr}$ balioa irudikatzen du, lurzoru eta uren analisien bidez lortu dena.

Hala eta guztiz ere, oxigeno eta estrontzio isotopo-konposizioak ez dira erabat aurreikus daitezkeenak; izan ere, denboran zehar eskuragarri diren elikagaiekin aldatuz joan daitezkeelako. Hori dela eta, isotopo hauen balioak gizakien aztarnen eta kokapenaren arteko lotura egokiena aurreikusteko erabiltzen dira.

\section{ONDORIOAK}

Gizakien hezur eta hortzetan neurtutako isotopo-erlazioak $\left(\delta^{13} \mathrm{C}, \delta^{15} \mathrm{~N}\right.$, $\delta^{18} \mathrm{O}$ eta ${ }^{87} \mathrm{Sr} /{ }^{86} \mathrm{Sr}$ ) lagungarriak dira antzinako populazioen bizimoduari buruzko informazioa lortzeko, alegia, zein zen haien elikadura, gizartean izan zitezkeen ezberdintasun sozialak, mugikortasuna eta jatorria azter daitezke, besteak beste.

Horrela, VI.-XIII. mendeetako aztarnategietako gizakien elikadura-ohiturak ezagutu izan ditugu, orojaleak ziren. Elikaduran denboran zeharreko ezberdintasunak ikusteko ere egokiak dira isotopo egonkorrak Momoitioko San Juan aztarnategiko gizakien kasuan, eta sexuaren eta adinaren araberako elikadura ezberdintasunak Tausteko biztanleriaren kasuan. Beste aldetik, populazioen mugikortasunari begira, garai honetan biztanleria orokorrean bertakoa da, eta soilik, gutxi batzuk dira kanpotik etorriak.

Hala ere, emaitzen irakurketak egiteko garaian kontuan hartu behar dira isotopo bakoitzaren arrazoietan eragiten duten elikaduraz kanpoko beste baldintzak: baldintza klimatiko, geologiko edo antropikoak, hain zuzen ere. 


\section{BIBLIOGRAFIA}

[1] LÜDERS, V. eta PLESSEN, B. 1984. «Carbon and Nitrogen Isotope Measurements of Gas-Bearing Fluid Inclusions: A Tool For Tracing Gas Sources and Maturity of Source Rocks». AAPG Annual Convention and Exhibition, California.

[2] LIAN, D., YANG, J., WIEDENBECK, M., DILEK, Y., ROCHOLL, A., eta WU, W. 2018. «Carbon and nitrogen isotope, and mineral inclusion studies on the diamonds from the Pozanti-Karsanti chromitite, Turkey». Contributions to Mineralogy and Petrology, 173,72.

[3] JAVOY, M., PINEAU, F. eta DEMAIFFE D. 1984. «Nitrogen and carbon isotopic composition in the diamonds of Mbuji Mayi (Zaïre)». Earth and Planetary Science Letters, 68 (3), 399-412.

[4] GILMOUR, I., RUSSELL, S. S., ARDEN, J. W., LEE, M. R., FRANCHI, I. A. eta PILLINGER C. T.1992. «Terrestrial carbon and nitrogen isotopic ratios from Cretaceous-Tertiary boundary nanodiamonds». Science, $\mathbf{2 5 8}$ (5088), 1624-1626.

[5] SCHOLLE, P.A. eta ARTHUR, M.A. 1980. «Carbon Isotope fluctuations in Cretaceous pelagic limestones: Potential stratigraphic and petroleum exploration tool». $A A P G, \mathbf{6 4}, 67-87$.

[6] SOFER, Z. 1984. «Stable Carbon isotope compositions of crude oils: Aplication to source depositional environments and petroleum alteration». $A A P G$, 68, 31-49.

[7] HOBBIE E.A., ETA QUIMITTE AP. 2009. «Controls of nitrogen isotope patterns in soil profiles». Biogeochemistry, 95(2-3), 355-371.

[8] MARTINELLI, L.A., PICCOLO, M.C., TOWNSEND, A.R., VITOUSEK, P.M., CUEVAS, E., MCDOWELL, W., ROBERTSON, G.P., SANTOS, O.C. eta TRESEDER, K. 1999. «Nitrogen stable isotopic composition of leaves and soil: Tropical versus temperate forest». Biogeochemistry, 46 (1-3), 45-65.

[9] RICHARDS, M.P. eta HEDGES, R.E.M. 1999. «Stable isotope evidence for similarities in the types of marine foods used by Late Mesolithic humans at sites along the Atlantic coast of Europe». Journal of Archaeological Science, 26, 717-722.

[10] OSTROM, M.H., MACKO, S.A., ENGEL, M.H., SILFER, J.A. eta RUSSELL, D. 1990. «Geochemical characterization of high molecular weigth organic material isolated from Late Cretaceous fossils». Organic Geochemistry, 16, 1139-1144.

[11] BOCHERENS, H., FIZER, H.M. eta MARIOTTI, A. 1994. «Diet, physiology and ecology of fossil mammals as inferred from stable carbon and nitrogen isotope biogeochemistry: implications for Pleistocene bears». Paleogeography Paleoclimatology Paleoecology, 107, 213-225.

[12] BOCHERENS, H., FIZER, H.M. eta MARIOTTI, A. 1990. «Mise en evidence alimentaire vegetarian de l'ours des caverns (Usus spelaeus) par la bi- 
Iranzu Guede, Ainhoa Alonso-Olazabal, Maria Cruz Zuluaga, Luis Angel Ortega

ogeochemie isotopique $(13 \mathrm{C}, 15 \mathrm{~N})$ des vertebres fossiles». CR Academia Science Paris Ser II, 311, 1279-1284.

[13] TÜTKEN, T., FURRER, H. eta VENNEMANN, T.W. 2007. «Stable isotope compositions of mammoth teeth from Niederweiningen, Switzrland: implications for the Late Pleistocene climate, environment and diet». Quaternary International, 164-165, 139-150.

[14] VAN DER MERWE, N.J., THACKERAY, J.F., LEE-THORP, J.A. eta LUYT, J. 2003. «The carbon isotope ecology and diet of Asutralopithecus africanus at Sterkfontein, South Africa». Journal of Human Evolution, 44, 581-597.

[15] BOCHERENS, H., FIZET, M., MARIOTTI, A., LANGE-BADRE, B., VANDERMEERSCH, B., BOREL, J.P. eta BELLON, G. 1991. «Isotopic biogeochemistry $(13 \mathrm{C}, 15 \mathrm{~N})$ of fossil vertebrate collagen: application to the study of a past food web including Neandertal man». Journal of Human Evolution, 20, 481-492.

[16] RICHARDS, M., HARVATI, K., GRIMES, V., SMITH, C., SMITH, T.M., HUBLIN, J.J., KARKANAS, P. eta PANAGOPOULOU, E. 2008. «Strontium isotope evidence of Neanderthal mobility at the site of Lakonis, Greece using laser-ablations PIMMS». Journal of Archaeological Science, 35 (5), 1251-1256.

[17] O'LEARY, M. 1981. «Carbon isotope fractionation in plants». Phytochemistry, 20, 553-567.

[18] SMITH, B.N. eta EPSTEIN, S. 1971. «Two categories of 13C/12C ratios for higher plants». Plant Physiology, 47, 380-384.

[19] SCHOENINGER, M.J. eta DENIRO, M.J. 1984. «Nitrogen and carbon isotopic composition of bone collagen from marine and terrestrial animals». Geochimica et Cosmochimica Acta, 48, 625-639.

[20] SCHWARCZ, H.P. eta SCHOENINGER, M.J. 1991. «Stable isotope analyses in human nutritional ecology». Yearbook of Physical Anthropology, 34, 283-321.

[21] LEE-THORP, J.A. 2008. «On Isotopes and Old Bones». Archaeometry, 50 (6), 925-950.

[22] SANDFORD, M.K. 1993. Investigations of Ancient Human Tissue: Chemical Analyses. Gordon and Breach, Langhorne.

[23] BOCHERENS, H. eta DRUCKER, D. 2003. «Trophic level enrichment of carbon and nitrogen in bone collagen: case studies from recent and terrestrial ecosystems». International Journal of Ostearchaeology, 13, 46-53.

[24] MARIOTTI A. 1984. «Natural ${ }^{15} \mathrm{~N}$ abundance measurements and atmospheric nitrogen standard calibration». Nature, 311, 251-252.

[25] SCHOENINGER, M.J. eta MOORE, K. 1992. «Bone stable isotope studies in archaeology». Journal of World Prehistory, 6, 247-296.

[26] FOGEL, M.L., TUROSS, N. eta OWSLEY, D.W. 1989. «Nitrogen Isotope Tracers of Human Lactation in Modern and Archaeological Populations». Annual Report of Geophysical Laboratory Carnegie Institution of Washington, 1987-1988, 111-117. 
[27] MALAINEY, M.E. 2011. A Consumer's Guide to Archaeological Science: Analytical Techniques. Springer, New York.

[28] FRASER, R.A., BOGAARD, A., HEATON, T., CHARLES, M., JONES, G., CHRISTENSEN, B.T., HALSTEAD, P., MERBACH, I., POULTON, P.R., SPARKES, D. ETA STYRING A.K. 2011. «Manuring and stable nitrogen isotope ratios in cereals and pulses: towards a new archaeobotanical approach to the inference of land use and dietary practices». Journal of Archaeological Science, 38, 2790-2804.

[29] RODRÍGUEZ-FERNÁNDEZ, L.R. eta TOMAS OLIVIERA, J. 2015. Mapa Geológico de la Península Ibérica, Baleares y Canarias a escala 1:1.000.000. SGE-IGME, Madrid.

[30] White, C.D., SPENCE, M.W., STUART-WILliAMS, H.L.Q. eta SCHWARCZ, H.P. 1998. «Oxygen isotopes and the identification of geographical origins: the Valley of Oaxaca versus the Valley of Mexico». Journal of Archaeological Science, 25, 643-655.

[31] PROWSE, T.L., SCHWARCZ, H.P., GARNSEY, P., KNYF, M., MACCHIARELLY, R. eta KONDIOLI, L. 2007. «Isotopic evidence for age-related inmigration to imperial Rome». American Journal of Physical Anthropology, 132, 510-519.

[32] EHLERINGER, J.R., BOWEN, G.J., CHESSON, L.A., WEST, A.G., PODLESAK, D.W. eta CERLING, T.E. 2008. «Hydrogen and oxygen isotope ratios in human hair are related to geography». Proceedings of the $\mathrm{Na}$ tional Academy of Sciences, 105, 2788-2793.

[33] STUART-WILLIAMS, H. eta SCHWARCZ, H.P. 1997. «Oxygen isotopic determination of climatic variation using phosphate from beaver bone, tooth enamel and dentine». Geochimica et Cosmochimica Acta, 61, 2539-2550.

[34] ZAZZO, A., SMITH, G.R., PATTERSON, W.P. eta DUFOUR, E. 2006. «Life history reconstruction of modern and fossil sockeye salmon (Oncorhynchus nerka) by oxygen isotopic analysis of otoliths, vertebrae, and teeth: Implication for paleoenviromental reconstructions». Earth Planet Science Letter, 249, 200-215.

[35] KILLINGLEY, J.S. 1980. «Migrations of California gray whales tracked by Oxygen-18 variations in their epizonic barnacles». Science, 207, 759-760.

[36] BALASSE, M., TRESSET, A., eta AMBROSE, S.H. 2006. «First evidence for seaweed winter foddering in the Neolithic of Scotland». Journal of Zoology, 270, 170-176.

[37] KELLY, J.F., RUEGG, K.C. eta SMITH, T.B. 2005. «Combining isotopic and genetic markers to identify breeding origins of migrant birds». Ecological Applicatons, 15, 1487-1494.

[38] DUFOUR, V., PELÉ, M., STERCK, E.H.M. eta THIERRY, B. 2007. «Chimpanzee anticipation of food return: coping with waiting time in an exchange task». Journal of Comparative Psychology 121, 145-155. 
Iranzu Guede, Ainhoa Alonso-Olazabal, Maria Cruz Zuluaga, Luis Angel Ortega

[39] LONGINELLI, A. 1984. «Oxygen isotopes in mammal bone phosphate: A new tool for paleohydrological and paleoclimatological search?». Geochimica et Cosmochimica Acta, 48, 385-390.

[40] IACUMIN, P. eta VENTURELLI, G. 2015. «The $\delta^{18} \mathrm{O}$ of phosphate of ancient human biogenic apatite can really be used for quantitative palaeoclimate reconstruction?». European Scientific Journal, 11 (9), 221-235.

[41] http://www.iaea.org/water. 2015.

[42] CAPILLA J.E., RODRIGUEZ AREVALO, J., CASTAÑO CASTAÑO, S., DÍAZ TEIJEIRO, M.F., SANCHEZ DEL MORAL, R. eta HEREDIA DIAZ J. 2011. Mapping oxygen-18 in meteoric precipitation over Peninsular Spain using geostatistical tools. Fall Meeting American Geophysical Union, San Francisco.

[43] EVANS, J., CHENERY, C. eta FITZPATRICK, A.P. 2006. «Bronze age childhood migration of individuals near Stonehenge, revealed by strontium and oxygen isotope tooth enamel analysis». Archaeometry, 48, 309-321.

[44] KNUDSON, K.J., O'DONNABHAIN, B., CARVER, C., CLELAND, R. eta PRICE, T.D. 2012. «Migration and Viking Dublin: paleomobility and paleodiet through isotopic analyses». Journal of Archaeological Science, 39 (2), 308-320.

[45] FAURE G, MENSING TM. 2005. Isotopes: Principles and Applications. Wiley, New Jersey.

[46] HILLSON S. 1996. Dental Anthropology. Cambridge University Press, London.

[47] RECKER R.R. 1983. Bone Histomorphometry: Techniques and Interpretation. CRC Press, Florida. 